\title{
EFFICACY OF INTRA-HEPATECTOMY 5-FU ON RECURRENCE AND METASTASIS OF HUMAN HEPATOCELLULAR CARCINOMA IN NUDE MICE
}

\author{
Babak Rashidi ${ }^{1,2}$, Zili AN ${ }^{1}$, Fang-Xian $\mathrm{SuN}^{1}$, Xiaoming $\mathrm{Li}^{1}$, Z.Y. TANG ${ }^{3}$, A.R. Moossa ${ }^{2}$ and Robert M. HofFMAN ${ }^{1,2 *}$ \\ ${ }^{1}$ AntiCancer, Inc., San Diego, CA, USA \\ ${ }^{2}$ Department of Surgery, University of California, San Diego, CA, USA \\ ${ }^{3}$ Liver Cancer Institute, Shanghai Medical University, Shanghai, China
}

\begin{abstract}
A novel intra-operative chemotherapy nude mouse model for human hepatocellular carcinoma (HCC) has been developed. Intra-peritoneal (i.p.) administration of 5-fluorouracil (5FU) was begun $2 \mathrm{hr}$ before hepatic resection of $\mathrm{HCC}$ and then continued post-operatively for $\mathbf{4}$ consecutive days. This regime, termed intra-hepatectomy chemotherapy (IHC), significantly prolonged animal survival compared with pre-operative 5-FU, neoadjuvant therapy, 5-FU post-operative adjuvant therapy, surgery alone, 5-FU without surgery, and the untreated control. The median survival of the intra-operative 5-FU-treated group was 127 days compared with 78 days for the neoadjuvantlytreated animals and 53 days for the control group $(p<0.006)$. When all animals with neoadjuvant 5-FU treatment had died, $60 \%$ of the animals in the IHC group were still alive $(p<0.0 \mathrm{II})$. Survival of all other treatment groups, including 5-FU without surgery, surgery alone, and adjuvant post-operative chemotherapy, was not significantly different from the untreated control group. Five animals in the IHC group were free of tumor when sacrificed at day 150 post-surgically. While $100 \%$ of animals in the control group had lymph nodes draining the liver involved with metastases, only $20 \%$ of animals in the IHC group had lymph node metastases. These data suggested that IHC therapy increased survival by preventing metastases of cancer cells not removed in the liver resection procedure. The results of this study indicate that IHC therapy for resection of HCC should be investigated clinically. (C) 2001 Wiley-Liss, Inc.
\end{abstract}

Key words: hepatocellular carcinoma; mice; intra-hepatectomy 5-Fu; chemotherapy

HCC is the most common primary malignant tumor of the liver. ${ }^{1}$ The incidence of HCC in the Far East and sub-Saharian Africa is 30 per 100,000 persons per year. ${ }^{2}$ In the United States, 13,000 new cases are expected annually. ${ }^{3,4}$ Surgery is the most effective current treatment for HCC. ${ }^{1}$ However, tumor recurrence after a curative liver resection is high, ${ }^{5-11}$ the reasons for which are: 1 . spreading of malignant cells into the portal circulation during surgical manipulation; ${ }^{11-13}$ 2. microscopic residual tumor cells after liver resection; ${ }^{11,13}$ 3. growth factors released early after liver resection. ${ }^{14-16}$

Repeated hepatectomy for recurrences after a curative liver resection benefits only a small group of patients, since most recurrent tumors are unresectable. ${ }^{12}$

Liver transplantation for HCC has also been associated with a high incidence of recurrence. ${ }^{7}$ Use of liver transplantation for treatment of $\mathrm{HCC}$ is limited due to an organ shortage and high cost. ${ }^{5-10}$ Adjuvant systemic chemotherapy with 5-FU and other drugs has not significantly improved the survival of HCC patients with recurrences after a curative liver resection. ${ }^{11,17-21}$ The results of post-operative intraarterial chemotherapy with lipiodol and percutaneous ethanol injection are limited. ${ }^{12,13,20}$ Intra-arterial chemoembolization also has not significantly increased the survival of patients with HCC. ${ }^{22,23}$

The search for new anticancer agents and treatment modalities has been impeded by the limited availability of clinically accurate mouse models, specifically highly metastatic models. Toward this goal, our laboratory has established clinically representative metastatic mouse models of human cancer with a novel method of surgical orthotopic implantation (SOI) of intact tumor tissue fragments. ${ }^{24-27}$ In our study, a highly metastatic human hepatocellular carcinoma nude mouse model was used. ${ }^{28}$
The aim of our study was to evaluate the efficacy of intraoperative 5-FU for the treatment of highly metastatic HCC in an orthotopic nude mouse model.

\section{MATERIAL AND METHODS}

Animals

Athymic nu/nu Balb/c mice of both sexes, 6-7 weeks old, were used in our study. The animals were maintained in a specific pathogen-free environment in compliance with USPHS guidelines governing the care and maintenance of experimental animals. All animal studies were conducted in accordance with the principles and procedures outlined in the National Institutes of Health Guide for the Care and Use of Animals under assurance number A3873-1. Mice were fed with an autoclaved laboratory rodent diet (Tecklad LM-485, Western Research Products, Orange, CA).

\section{Human hepatocellular carcinoma}

A highly metastatic human hepatocellular carcinoma nude mouse model, LCI-D20, was previously established by surgical orthotopic implantation (SOI). ${ }^{28}$

\section{Tumor implantation on the nude mice liver}

In the present study, LCI-D20 human hepatoma tissue fragments were implanted by SOI directly on the left lobe of the liver in 60 animals using the following methods: Liver metastases of LCID20 that originated from SOI to the liver of nude mice were harvested and carefully inspected under a dissecting microscope $(5 \times)$ to remove necrotic tissue. The harvested tumor tissues were then equally divided into small pieces of $1 \mathrm{~mm}^{3}$ each. Tumor tissue fragments were mixed thoroughly before the implantation procedure to ensure that each mouse received equally viable tissues. The left lobe of the liver of the mice was isolated via a left subcostal incision under isoflurane anesthesia. A small cut was then made on the glissonian capsule. Three $1 \mathrm{~mm}^{3}$ pieces of the above tumor tissue fragments were inserted into the incision on the left lobe and then fixed in place using an 8-0 nylon suture. The abdomen was closed with a 6-0 silk suture using different instruments than those used for tumor implantation in order to prevent any tumor cell seeding at the incision site.

\section{Partial hepatectomy}

Mice were anesthetized with isoflurane inhalation and put in a supine position. The abdomen was sterilized with iodine and alcohol swabs. To prevent any residual tumor growth, the left subcostal incision site, which was used for tumor implantation, was completely excised. Through this abdominal wall opening, the tumor-bearing left lobe of the liver was isolated and its biliovascular bundle ligated with a 6-0 nylon suture. Then the entire left

*Correspondence to: AntiCancer, Inc., 7917 Ostrow Street, San Diego, CA 92111. Tel: 858-654-2555. Fax: 858-268-4175.

E-mail: all@anticancer.com

Received 3 May 2000; Revised 21 July 2000 
lobe was resected. The incision line was at least $1 \mathrm{~cm}$ distant from the liver metastasis. The resected lobe corresponded to approximately $30 \%$ of the total liver. The abdomen was then closed with a 6-0 silk suture using different instruments than those used for the resection to prevent any tumor spreading at the incision site.

\section{Chemotherapeutic study design}

5-FU (Calbiochem-Novabiochem, San Diego, CA) was used at $20 \mathrm{mg} / \mathrm{kg} / 0.5 \mathrm{ml}$ i.p. There were 6 groups of animals in this study. In group 1, the control animals were treated with saline, $0.5 \mathrm{ml}$, once a day for 5 days. In group 2, animals were treated with 5-FU only once a day for 5 days, with the first dose starting 3 days after tumor implantation. In group 3 , a curative liver resection was performed 3 days after tumor implantation. In group 4, which received adjuvant treatment, animals were first given a curative liver resection, then after 2 days of rest, were subsequently treated with 5-FU once a day for 5 days. In group 5, which received neoadjuvant treatment, animals were treated with 5-FU once a day for 5 days, then after 2 days of rest, a curative liver resection was performed. In group 6, intra-hepatic chemotherapy (IHC), the first 5-FU dose was given to the animals $2 \mathrm{hr}$ prior to liver resection. Four more daily doses of 5-FU were given to the animals beginning from the first post-operative day (Table I).

\section{Statistical analysis}

The incidence of survival at defined time points and the incidence of metastasis was analyzed using the Fisher exact test. Median survival was analyzed using the Wilcoxon rank-sum test.

\section{RESULTS}

\section{Survival}

All animals were sacrificed when they became moribund. Five animals in the IHC treatment group did not show any sign of neoplastic disease and were sacrificed at day- 150 post-tumor implantation. Animals with IHC survived much longer than all other treatment or control groups (Fig. 1). The median survival of the IHC group was 127 days compared with 53 days for the control group $(p<0.006)$. The median survival of animals in the neoadjuvant group was 78 days $(p<0.021$ compared with the control group). Though survival of animals in the surgery-alone, 5-FU-

TABLE I - TREATMENT REGIMENS OF HUMAN HEPATOCELLULAR CARCINOMA IN THE LIVER OF NUDE MICE

\begin{tabular}{|c|c|c|}
\hline Group & $\begin{array}{l}\text { No. of } \\
\text { animals }\end{array}$ & $\begin{array}{c}\text { Therapeutic regimens listed in order } \\
\text { of use }\end{array}$ \\
\hline (1) Control & 9 & $\begin{array}{l}\text { Saline } 0.5 \mathrm{ml} \text {, once a day } \\
\text { for } 5 \text { days. }\end{array}$ \\
\hline (2) 5-FU alone & 8 & $\begin{array}{l}20 \mathrm{mg} / \mathrm{kg} / 0.5 \mathrm{ml} \text { once a day } \\
\text { for } 5 \text { days; first dose } 3 \\
\text { days after tumor } \\
\text { implantation. }\end{array}$ \\
\hline $\begin{array}{l}\text { (3) Liver resection } \\
\text { alone }\end{array}$ & 10 & $\begin{array}{l}\text { Curative liver resection } 3 \\
\text { days after tumor } \\
\text { implantation. }\end{array}$ \\
\hline (4) Adjuvant & 8 & $\begin{array}{l}\text { Curative liver resection }+2 \\
\text { days rest }+5-\mathrm{FU} 20 \mathrm{mg} / \\
\mathrm{kg} / 0.5 \mathrm{ml} \text { once a day for } \\
5 \text { days. }\end{array}$ \\
\hline (5) Neoadjuvant & 8 & $\begin{array}{l}\text { 5-FU } 20 \mathrm{mg} / \mathrm{kg} / 0.5 \mathrm{ml} \text { once } \\
\text { a day for } 5 \text { days }+2 \\
\text { days rest }+ \text { curative liver } \\
\text { resection. }\end{array}$ \\
\hline $\begin{array}{l}\text { (6) Intra-hepatectomy } \\
\text { chemotherapy }\end{array}$ & 10 & $\begin{array}{l}\text { 5-FU } 20 \mathrm{mg} / \mathrm{kg} / 0.5 \mathrm{ml} \text {, first } \\
\text { dose } 2 \text { hr prior to } \\
\text { curative liver resection }+ \\
4 \text { more doses beginning } \\
\text { from post-operative first } \\
\text { day. }\end{array}$ \\
\hline
\end{tabular}

alone and adjuvant post-operative 5-FU groups was longer than the control group, it was not statistically significant. When all animals with neoadjuvant 5-FU treatment had died, $60 \%$ of animals with IHC were still alive $(p<0.011)$ (Table II).

\section{Systemic metastasis}

All animals were explored for metastasis at necropsy. In the control group, $100 \%$ of the animals had metastasis in lymph nodes draining the liver. In animals treated with 5-FU alone, $100 \%$ of the animals had lymph node metastases. In animals treated with surgical resection only without chemotherapy, $75 \%$ of the animals had lymph node metastases. In animals treated with surgery and subsequently adjuvant chemotherapy, $63 \%$ of the animals had lymph node metastases. In the neoadjuvant chemotherapy group, $63 \%$ of the animals had lymph node metastases. In the IHC group, only 2 animals had lymph node metastases (20\%). Peritoneal carcinomatosis occurred in $67 \%$ of animals in the control group and in only $10 \%$ of animals treated with IHC $(p<0.020)$. Five mice treated with IHC sacrificed at day-150 post-tumor implantation were found free of neoplastic disease. All other animals in all groups had recurrences of tumor in the liver. The metastatic patterns and frequency in the different treatment groups are shown in Table III.

\section{DISCUSSION}

Adjuvant, post-operative and standard chemotherapeutic regimes have not significantly improved survival of patients with HCC. ${ }^{17-19}$ Early recurrence in the remnant liver after a curative liver resection is high. ${ }^{5-11}$ The reasons for recurrences in the residual liver after a curative liver resection are believed to be due to microscopic residual foci of tumor or spreading of malignant cells by surgical manipulation or both. ${ }^{11,13}$ It is known that surgical manipulation spreads HCC cells into the portal circulation. ${ }^{12,19,29}$

In recent years, a number of reports have suggested that at least small HCC are mainly supplied by the portal circulation. ${ }^{11,29-31}$ As HCC increase in size and become increasingly dedifferentiated, the number of portal tracts apparently decreases and intratumoral arterioles develop. ${ }^{11}$ In larger HCC, the portal circulation also has an important role and could become the main supplier after adjuvant, post-operative, intra-arterial chemoembolization. ${ }^{31}$

Pharmacokinetic and phase- 1 clinical studies have indicated that i.p. administration of 5-FU achieves drug concentrations in the peritoneal cavity between 300 and 2,200 times higher than in the systemic circulation. ${ }^{32-35}$ Anatomic considerations and experimental data suggest that a major mechanism of clearance of compounds placed into the peritoneal cavity is by way of the portal circulation. ${ }^{32-35}$ The delivery of the drug to the liver by way of the portal circulation essentially equals the amount of drug entering the liver during intrahepatic artery infusion. ${ }^{32-35}$

Several clinical trials studied whether perioperative adjuvant portal vein injection in patients with colon cancer can prevent recurrences in the liver. ${ }^{36-38}$ In Taylor's study, benefit was seen in patients with Dukes' B. The Weber and Wolmark studies showed an increase of survival in patients who received adjuvant intraportal infusion of chemotherapy after resection of their primary colon tumor. However, none of these studies demonstrated a decrease in the incidence of liver metastases ${ }^{36-38}$ in contrast to IHC, which demonstrates a significant decrease.

The reason for accelerated tumor growth after hepatectomy seems to be due to growth factors, such as hepatocyte growth factor and transforming growth factor- $\alpha$, secreted from the residual liver of both humans and mice during the first week after a partial hepatectomy. ${ }^{14,39}$ In a previous study, we demonstrated an increase of human colon cancer growth implanted into the liver of nude mice after $30 \%$ hepatectomy. ${ }^{15}$ The timing of initiation of chemotherapy in our study is important for 2 reasons: 1 . the potential effect of growth factors that can stim- 


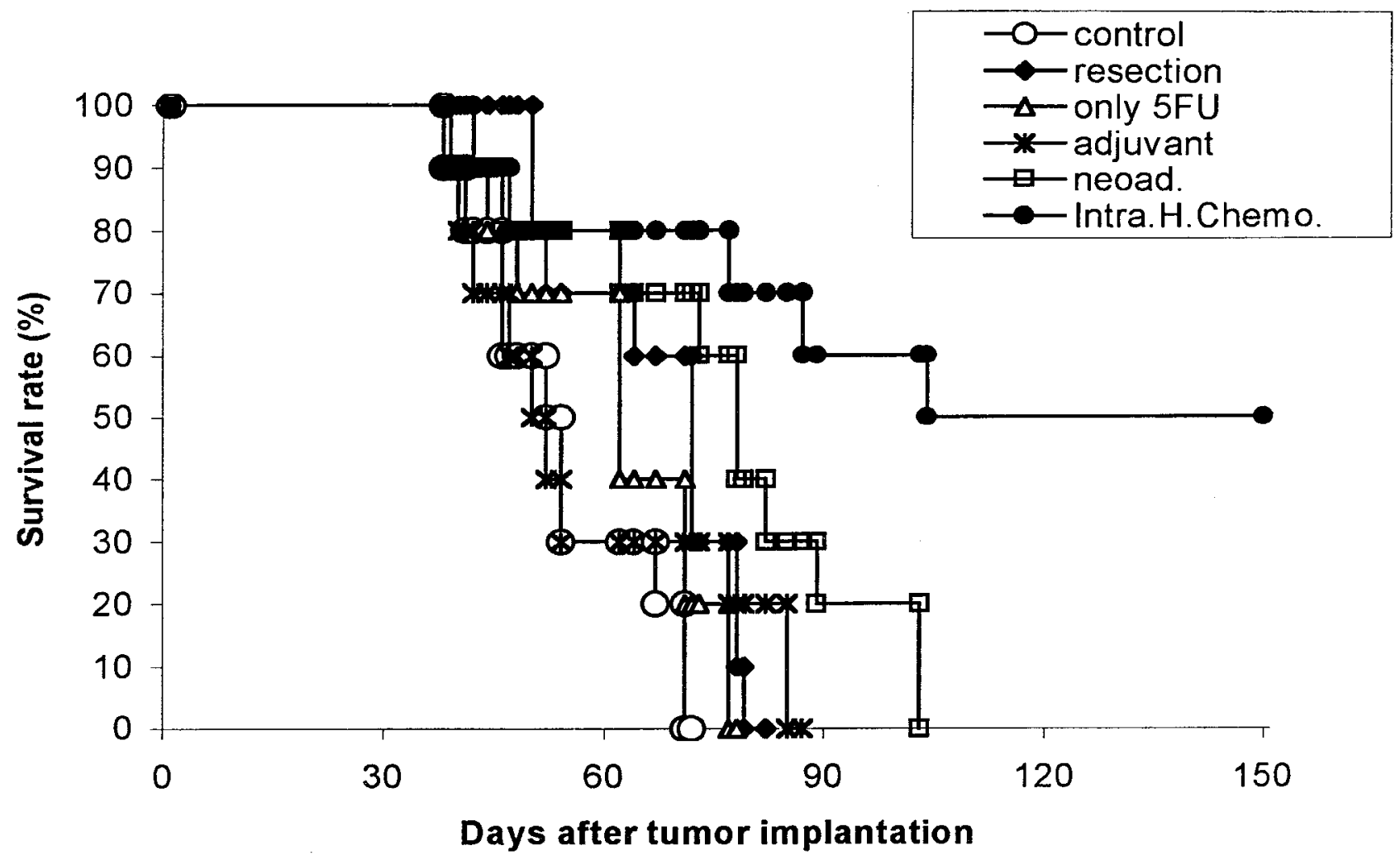

FigURE 1 - 5-FU was used at $20 \mathrm{mg} / \mathrm{kg} / 0.5 \mathrm{ml}$ i.p. There were 6 groups of animals in this study. In group 1 , the control animals were treated with saline $0.5 \mathrm{ml}$, once a day for 5 days. In group 2, animals were treated with 5-FU only once a day for 5 days; the first dose starting 3 days after tumor implantation. In group 3, a curative liver resection was performed 3 days after tumor implantation. In group 4, adjuvant treatment, animals were first given a curative liver resection; then after 2 days of rest, were subsequently treated with 5-FU once a day for 5 days. In group 5 , which received neoadjuvant treatment, animals were treated with 5-FU once a day for 5 days, then after 2 days of rest, a curative liver resection was performed. In group 6, intra-hepatic chemotherapy (IHC), the first 5-FU dose was given to the animals 2 hr prior to liver resection. Four more daily doses of 5-FU were given to the animals beginning from the first post-operative day (also see Table 1).

TABLE II - SURVIVAL EFFICACY OF INTRA-HEPATECTOMY CHEMOTHERAPY COMPARED WITH STANDARD TREATMENT MODALITIES IN NUDE MICE

\begin{tabular}{|c|c|c|c|c|c|c|c|c|c|c|}
\hline \multirow{2}{*}{ Group } & \multicolumn{2}{|c|}{$\begin{array}{l}\text { At the time when all } \\
\text { mice in the control had } \\
\text { died }\end{array}$} & \multicolumn{2}{|c|}{$\begin{array}{l}\text { At the time when all } \\
\text { mice in the 5-FU } \\
\text { group had died } \\
\end{array}$} & \multicolumn{2}{|c|}{$\begin{array}{l}\text { At the time when all } \\
\text { mice in the surgery } \\
\text { group had died }\end{array}$} & \multicolumn{2}{|c|}{$\begin{array}{l}\text { At the time when all } \\
\text { mice in the adjuvant } \\
\text { group had died }\end{array}$} & \multicolumn{2}{|c|}{$\begin{array}{l}\text { At the time when all mice in } \\
\text { the neoadjuvant group had died }\end{array}$} \\
\hline & $\begin{array}{l}\text { Survival } \\
\text { rate }(\%)\end{array}$ & $\begin{array}{c}p \text {-value* } \\
\text { vs. control }\end{array}$ & $\begin{array}{l}\text { Survival } \\
\text { rate }(\%)\end{array}$ & $\begin{array}{l}p \text {-value* } \\
\text { vs. } 5 \text {-FU }\end{array}$ & $\begin{array}{l}\text { Survival } \\
\text { rate }(\%)\end{array}$ & $\begin{array}{c}p \text {-value* } \\
\text { vs. surgery }\end{array}$ & $\begin{array}{l}\text { Survival } \\
\text { rate }(\%)\end{array}$ & $\begin{array}{c}p \text {-value* } \\
\text { vs. adjuvant }\end{array}$ & $\begin{array}{l}\text { Survival } \\
\text { rate }(\%)\end{array}$ & $\begin{array}{c}p \text {-value* } \\
\text { vs. neoadjuvant }\end{array}$ \\
\hline Control & 0 & - & 0 & - & 0 & - & 0 & - & 0 & 0 \\
\hline 5-FU & 20 & 0.474 & 0 & - & 0 & - & 0 & - & 0 & 0 \\
\hline Surgery & 60 & 0.011 & 30 & 0.211 & 0 & - & 0 & - & 0 & 0 \\
\hline Adjuvant & 30 & 0.211 & 20 & 0.474 & 20 & 0.474 & 0 & - & 0 & 0 \\
\hline Neoadjuvant & 70 & 0.003 & 60 & 0.011 & 40 & 0.087 & 30 & 0.211 & 0 & - \\
\hline $\begin{array}{l}\text { Intra-hepatectomy } \\
\text { chemotherapy }\end{array}$ & 80 & 0.001 & 70 & 0.003 & 70 & 0.003 & 70 & 0.003 & 60 & 0.011 \\
\hline
\end{tabular}

*All $p$-values were derived from the $\chi^{2} /$ Fisher exact test.

ulate tumor growth released early after liver resection; 2. surgical manipulation spreads malignant cells into the portal circulation. ${ }^{12,19,29}$ The highest concentration of 5-FU after i.p. injection on liver tumors is reached after $2 \mathrm{hr} .{ }^{40}$ Therefore, in our study, in the IHC group, the first dose of 5-FU was injected i.p. $2 \mathrm{hr}$ before the start of the operation. The other 4 doses were administered daily from the first post-operative day through day-4.

The IHC strategy significantly prolonged survival and in 5 of 10 animals prevented tumor recurrence. Despite the recurrences of tumor in the liver in 5 of the animals treated with IHC 5-FU, lymph node metastases draining the liver occurred in only 2 animals and peritoneal carcinomatosis in only 1 animal (Table III). The IHC thus seemingly reduced the malignancy of the tumor.

The data in our study demonstrated that IHC for resectable $\mathrm{HCC}$ is an effective and convenient procedure. IHC therapy does not have the disadvantage of neoadjuvant chemotherapy in which a resectable tumor remains in the liver parenchyma with the possibility of becoming nonoperable in case there is no response to chemotherapy. ${ }^{41}$ The results of this study indicate that IHC for resection of HCC should be investigated clinically. 
TABLE III - EFFICACY OF INTRA-HEPATECTOMY CHEMOTHERAPY COMPARED WITH STANDARD TREATMENT MODALITIES ON GROWTH AND METASTASIS OF HCC IN NUDE MICE

\begin{tabular}{|c|c|c|c|c|c|c|c|}
\hline Group & $\begin{array}{l}\text { No. of mice } \\
\text { analyzed in } \\
\text { each group }\end{array}$ & $\begin{array}{l}\text { Mean tumor } \\
\text { weight }(\mathrm{g}) \\
\quad+\mathrm{SD}\end{array}$ & $\begin{array}{c}p \text {-value }{ }^{1} \\
\text { compared with } \\
\text { the control }\end{array}$ & $\begin{array}{l}\text { Lymph node } \\
\text { metastasis }\end{array}$ & $\begin{array}{c}p \text {-value }{ }^{2} \\
\text { compared with } \\
\text { the control }\end{array}$ & $\begin{array}{c}\text { Peritoneal } \\
\text { carcinomatosis }\end{array}$ & $\begin{array}{c}p \text {-value }{ }^{3} \\
\text { compared with } \\
\text { the control }\end{array}$ \\
\hline Control & 9 & $8.8+3.14$ & - & $9 / 9$ & - & $6 / 9$ & - \\
\hline Surgery & 8 & $6.9+4.64$ & 0.834 & $6 / 8$ & 0.206 & $2 / 8$ & 0.153 \\
\hline $5-\mathrm{FU}$ & 10 & $9.1+1.75$ & 1.000 & $10 / 10$ & 1.000 & $6 / 10$ & 1.000 \\
\hline Adjuvant & 8 & $6.8+4.02$ & 0.878 & $5 / 8$ & 0.082 & $2 / 8$ & 0.153 \\
\hline Neoadjuvant & 8 & $7.1+3.56$ & 0.846 & $5 / 8$ & 0.082 & $3 / 8$ & 0.347 \\
\hline $\begin{array}{l}\text { Intra-hepatectomy } \\
\text { chemotherapy }\end{array}$ & 10 & $2.7+2.90$ & 0.003 & $2 / 10$ & 0.001 & $1 / 10$ & 0.020 \\
\hline
\end{tabular}

${ }^{1}$ By the ANOVA test. ${ }^{2,3}$ By the $\chi^{2} /$ Fisher exact test.

\section{REFERENCES}

1. Mor E, Kaspa RT, Sheiner P, Schwartz M. Treatment of hepatocellular carcinoma associated with cirrhosis in era of liver transplantation. Ann Intern Med 1998;129:643-653.

2. Colombo M. Hepatocellular carcinoma. J Hepatol 1992;15:225-236.

3. Flye MW, McCullough CS. Liver transplantation for malignant disease. Principles and practice of oncology, PPO updates, 4th ed., vol. 3, Philadelphia: Lippincott, 1989:1-12.

4. Falkson G, Cnaan A, Schutt AJ, Ryan LM, Falkson HC. Prognostic factors for survival in hepatocellular carcinoma. Cancer Res 1988;48: 7314-7318.

5. McPeake JR, O'Grady JG, Zaman S, Portmann B, Wight DG, Tan $\mathrm{KC}$, Calne RY, Williams R. Liver transplantation for primary hepatocellular carcinoma: tumor size and number determine outcome. J Hepatol 1993;18:226-234.

6. Romani F, Belli LS, Rondinara GF, DeCarlis L, Rimoldi P, Riolo F, Bellati $G$, Ideo $G$, Belli $L$. The role of transplantation in small hepatocellular carcinoma complicating cirrhosis of the liver. J Am Coll Surg 1994;178:379-384.

7. Mazzaferro V, Regalia E, Doci R, Andreola S, Pulvirenti A, Bozzetti F, Montalto F, Ammatuna M, Morabito A, Gennari L. Liver transplantation for the treatment of small hepatocellular carcinomas in patients with cirrhosis. N Engl J Med 1996;334:693-699.

8. Ringe B, Wittekind C, Bechstein WO, Bunzendahl H, Pichlmayr R. The role of liver transplantation in hepatobiliary malignancy. Ann Surg 1989;209:88-98.

9. Iwatsuki S, Starzl TE, Sheahan DG, Yokoyama I, Demetris AJ, Todo S, Tzakis AG, Van Thiel DH, Carr B, Selby R, et al. Hepatic resection versus transplantation for hepatocellular carcinoma. Ann Surg 1991; 214:221-228.

10. Bismuth H, Chiche L, Adam R, Castaing G, Diamond T, Dennison A. Liver resection versus transplantation for hepatocellular carcinoma in cirrhotic patients. Ann Surg 1993;218:145-151.

11. Nakashima Y, Nakashima O, Hsia CC, Kojiro M, and Tabor E. Vascularization of small hepatocellular carcinomas: correlation with differentiation. Liver 1999;19:12-18.

12. Poon RT, Fan ST, Lo CM, Liu CL, Wong J. Intrahepatic recurrence after curative resection of hepatocellular carcinoma. Long-term results of treatment and prognostic factors. Ann Surg 1999;229: $216-222$.

13. Izumi R, Shimizu K, Miyazaki I. Postoperative adjuvant locoregional chemotherapy in patients with hepatocellular carcinoma. Hepatogastroenterology 1996;43:1415-1420.

14. Mitzutani J, Hiraoka T, Yamashita R, Miyauchi Y. Promotion of hepatic metastases by liver resection in the rat. Brit J Cancer 1992; 65:794-797.

15. Rashidi B, An Z, Sun F-X, Sasson A, Gamagammi R, Moossa AR, Hoffman RM. Minimal liver resection strongly stimulates the growth of human colon cancer in the liver of nude mice. Clin Exp Metastasis 1999; 17:497-500.

16. Rashidi B, An Z, Sun F-X, Moossa AR, Hoffman RM. Anti-metastatic intra-operative chemotherapy of human colon tumors in the liver of nude mice. Clin Cancer Res 2000;6:2464-2468.

17. Ono T, Nagasue N, Kohno H, Hayashi T, Uchida M, Yukaya H, Yamanoi A. Adjuvant chemotherapy with epirubicin and carmofur after radical resection of hepatocellular carcinoma: a prospective randomized study. Semin Oncol 1997;24:S6-18-S6-25.

18. Lai EC, Lo CM, Fan ST, Liu CL, Wong J. Postoperative adjuvant chemotherapy after curative resection of hepatocellular carcinoma: a randomized controlled trial. Arch Surg 1998;133:183-188.

19. Kanmematsu T. Is postoperative chemotherapy effective for the pre- vention of recurrence after surgery for hepatocellular carcinoma? Hepatogastroenterology 1996;43:1404.

20. Nagasue N, Yukaya H, Chang YC, Yamanoi A, Kohno H, Hayashi T, Nakamura T. Assessment of patients and treatment of intrahepatic recurrence after resection of hepatocellular carcinoma. Surg Gynecol Obstet 1990;171:217-222.

21. Sitzmann JV, Abrams R. Improved survival of hepatocellular cancer with combination surgery and multimodality treatment. Ann Surg 1993;217:149-154.

22. Geschwind JH, Huncharek MS, Thuluvat J, Choti M, Lund GB, Venbrux AC, Soulen MC, Abrams RA. Chemoembolization of hepatocellular carcinoma: results of a metaanalysis. Proc AACR 2001; 41:504 (abstract 3212).

23. Trinchet JC, Ganne-Carrie N, Beaugrand M. Intra-arterial chemoembolization in patients with hepatocellular carcinoma. Hepatogastroenterology 1998;45:1242-1247.

24. Fu XY, Besterman JM, Monosov A, Hoffman RM. Models of human metastatic colon cancer in nude mice orthotopically constructed by using histologically intact patient specimens. Proc Nat Acad Sci (Wash) 1991;88:9345-9349.

25. Fu X, Guadagni F, Hoffman RM. A metastatic nude mouse model of human pancreatic cancer constructed orthotopically with histologically intact patient specimens. Proc Nat Acad Sci (Wash) 1992;89: 5645-5649.

26. An Z, Jiang P, Wang X, Moossa AR, Hoffman RM. Development of a high metastatic orthotopic model of human renal cell carcinoma in nude mice: benefits of fragment implantation compared to cell-suspension injection. Clin Exp Metastasis 1999;17:265-270.

27. Hoffman RM. Orthotopic metastatic mouse models for anticancer drug discovery and evaluation: a bridge to the clinic. Invest New Drugs, 1999;17:343-59.

28. Sun FX, Tang ZY, Liu KD, Ye SL, Xue Q, Gao DM, Ma ZC. Establishment of a metastatic model of human hepatocellular carcinoma in nude mice via orthotopic implantation of histologically intact tissues. Int J Cancer 1996;66:239-243.

29. Yamanaka N, Okamoto E, Fujihara S, Kato T, Fujimoto J, Oriyama T, Mitsunobu M, Toyosaka A, Uematsu K, Yamamoto K. Do the tumor cells of hepatocellular carcinomas dislodge into portal venous stream during hepatic resection? Cancer 1992;70:2263-2267.

30. Taniguchi H, Daidoh T, Shioaki Y, Takahashi T. Blood supply and drug delivery to primary and secondary human liver cancers studied with in vivo bromodeoxyuridine labeling. Cancer 1993;71:5055 .

31. Goseki N, Nosaka T, Endo M, Koike M. Nourishment of hepatocellular carcinoma cells through the portal blood flow with and without transcatheter arterial embolization. Cancer 1995;76:736-742.

32. Speyer JL, Collins JM, Dedrick RL, Brennan MF, Buckpitt AR, Londer H, DeVita VT Jr., Myers CE. Phase I pharmacological studies of 5-fluorouracil administrated intraperitoneally. Cancer Res 1980;40: $567-572$.

33. Speyer JL, Sugarbaker PH, Collins JM, Dedrick RL, Klecker RW Jr., Myers CE. Portal levels and hepatic clearance of 5-fluorouracil after intraperitoneal administration in humans. Cancer Res 1981;41:19161922.

34. Gyves J. Pharmacology of intraperitoneal infusion of 5-fluorouracil and mitomycin-C. Semin Oncol 1985;12:29-32.

35. Lukas G, Brindle S, Greengard P. The route of absorption of intraperitoneally administrated compounds. J Pharmacol Exp Ther 1971; 178:562-564

36. Taylor I, Machin D, Mullee M, Trotter G, Cooke T, West C. A 
randomized controlled trial of adjuvant portal vein cytotoxic perfusion in colorectal cancer. Brit J Surg 1985;72:359-362.

37. Weber W, Laffer U, Metzger U. Adjuvant portal liver infusion with 5-fluorouracil and mitomycin in colorectal cancer. Anticancer Res 1993; 13:1839-1840

38. Wolmark N, Rokette H, Wickerham DL, Fisher B, Redmond C, Fisher ER, Potvin M, Daivies RJ, Robidoux A. Adjuvant therapy of Dukes' A, $\mathrm{B}$ and $\mathrm{C}$ adenocarcinoma of the colon with portal vein fluorouracil hepatic infusion: preliminary results of National Surgical Adjuvant Breast and Bowel Project Protocol C-02. J Clin Oncol 1990;8:1466-1475.
39. Gutman M, Singh R, Price J, Fan D, Fidler I. Accelerated growth of human colon cancer cells in nude mice undergoing liver regeneration. Invasion Metastases 1994-1995;14:362-371.

40. Mahteme H, Larsson BS, Sundin A, Graf W. 5-FU uptake in liver metastases after intravenous and intraperitoneal administration: an autoradiographic study in the rat. Anticancer Res 1998;18:943-949.

41. Bismuth H, Adam R, Levi F, Farabos C, Waechter F, Castaing D, Majno P, Engerran L. Resection of nonresectable liver metastases from colorectal cancer after neoadjuvant chemotherapy. Ann Surg 1996;224:509-520. 